\title{
Remote Microgrids for Energy Access in Indonesia-Part II: PV Microgrids and a Technology Outlook
}

\author{
Desmon Simatupang ${ }^{1, *(\mathbb{D})}$, Ilman Sulaeman ${ }^{1}\left(\mathbb{D}\right.$, Niek Moonen ${ }^{1}\left(\mathbb{D}\right.$, Rinaldi Maulana ${ }^{2}$, Safitri Baharuddin ${ }^{3} \mathbb{D}$, \\ Amalia Suryani ${ }^{4}$, Jelena Popovic ${ }^{1,5}$ and Frank Leferink ${ }^{1,6}$ (D) \\ 1 Faculty of Electrical Engineering, Mathematics and Computer Science (EEMCS), University of Twente, \\ 7522 NB Enschede, The Netherlands; i.sulaeman@utwente.nl (I.S.); niek.moonen@utwente.nl (N.M.); \\ j.popovic@utwente.nl (J.P.); frank.leferink@utwente.nl (F.L.) \\ 2 Perusahaan Listrik Negara (PLN), Jakarta 15418, Indonesia; maulana.rinaldi@pln.co.id \\ 3 NZMATES, Kota Ambon 97121, Indonesia; safitri@nzmates.org \\ 4 Faculty of Economics, Leipzig University, 04109 Leipzig, Germany; amalia.suryani@web.de \\ 5 Klimop Energy, 7001 EX Doetinchem, The Netherlands \\ 6 Thales Netherlands, 7554 RR Hengelo, The Netherlands \\ * Correspondence: desmonpetrus@ymail.com
}

Citation: Simatupang, D.; Sulaeman,

I.; Moonen, N.; Maulana, R.;

Baharuddin, S.; Suryani, A.; Popovic,

J.; Leferink, F. Remote Microgrids for Energy Access in Indonesia-Part II: PV Microgrids and a Technology Outlook. Energies 2021, 14, 6901. https://doi.org/10.3390/en14216901

Academic Editor: Adel Merabet

Received: 31 August 2021

Accepted: 19 October 2021

Published: 21 October 2021

Publisher's Note: MDPI stays neutral with regard to jurisdictional claims in published maps and institutional affiliations.

Copyright: (c) 2021 by the authors Licensee MDPI, Basel, Switzerland. This article is an open access article distributed under the terms and conditions of the Creative Commons Attribution (CC BY) license (https:// creativecommons.org/licenses/by/ $4.0 /)$.

\begin{abstract}
This paper is the companion paper of Remote Microgrids for Energy Access in Indonesia "Part I: scaling and sustainability challenges and a technology outlook". This part II investigates the issues of photovoltaic (PV) systems with respect to the planning, design, and operation, and maintenance phases in microgrids in Indonesia. The technology outlooks are also included as PV has an important role in providing electricity in the underdeveloped, isolated, and border areas. The data in this paper are from PV microgrids located in Maluku and North Maluku, which are two provinces where there is barely any grid connection available and thus very dependent on remote microgrids. The data are obtained from interviews with Perusahaan Listrik Negara (PLN) and NZMATES, which are an Indonesian utility company and a program for supporting role for the PV systems in Maluku funded by New Zealand respectively. Common issues with respect to reliability and sustainability are identified based on the provided data. Advanced technologies to increase reliability and sustainability are also presented in this paper as a technology outlook. Among these solutions are online monitoring systems, PV and battery lifetime estimation, load forecasting strategies, and PV inverters technology.
\end{abstract}

Keywords: microgrids; photovoltaic; technology outlook; Maluku and North Maluku

\section{Introduction}

Indonesia is predicted to reach the peak of demographic dividend (when the population in working ages will be at the highest) between 2020-2030 [1] which theoretically has the potential to increase investments and output per capita. Consequently, Indonesia will face a significant challenge to provide (clean) energy everywhere. Since Indonesia is an island country, the development of a fully interconnected grid is a challenge. Many isolated islands or rural areas are not covered by the grid due to the lack of development and investment. The energy access disparity between the western part and eastern part in Indonesia is clearly prominent [2,3]. Western islands like Sumatra, Java, and Bali are oversupplied while the eastern islands like Maluku and North Maluku (MMU) have been struggling for a long time. This can be seen in Figure 1, where the electrification ratio per region is shown. The situation gets even worse when assessing the energy access attribute based on a multi-tier framework as was shown in part I of this publication.

Indonesia has committed to increasing the penetration of renewable energy to $23 \%$ and 29\% in 2025 and 2030, respectively, as per Paris Agreement on Climate Change (UNFCCC). However, the total power generation is still mainly driven by coal power plants. Coal power plants contribute $49.85 \%$, followed by gas power plants $28.06 \%$, and diesel generators by 
$7.03 \%$, while renewable energy gives a $15.06 \%$ contribution of total plants capacity [4]. Hydro-based powerplants are the biggest clean energy providers in Indonesia accounting for approximately $11.55 \%$ of the total energy generated. Alternative clean energy sources used are geothermal (3.00\%), wind (0.22\%) and PV $(0.09 \%)$ [5]. It can be clearly seen that Indonesia needs to reshape the focus more on renewable energy, to reach their targeted percent in 2025 and 2030.

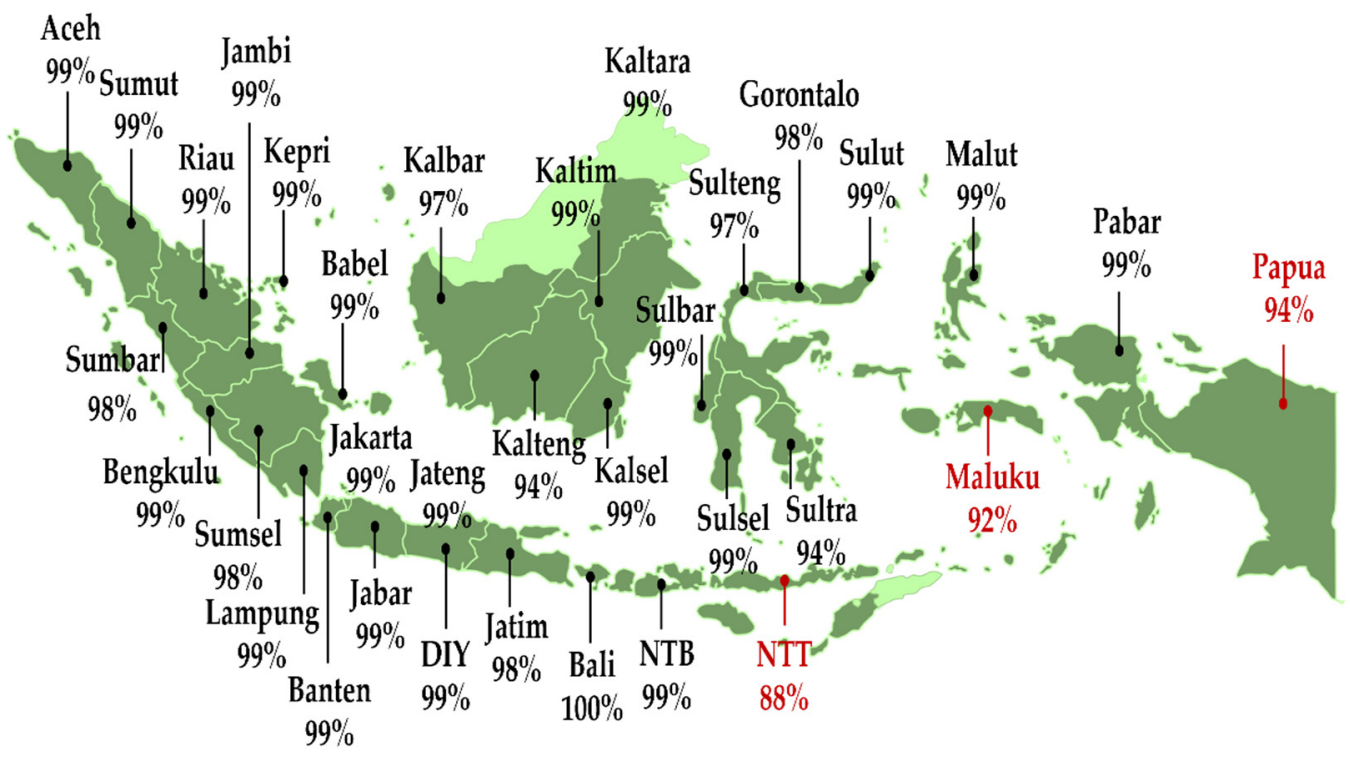

Figure 1. Electrification ratio in each province in Indonesia [3].

Even though there are already more than a hundred outlying islands in Indonesia [6] that have been using PV off-grid, their impact on total energy generation is still too little. Therefore, the government has started actively supporting the usage of PV off-grid by providing funding to remote communities through the Ministry of Energy and Mineral Resources (MEMR). Tutukembung, Adaut, Wamana, and Ilwaki in the Maluku Province are examples of communities that already gained electricity access through that funding. PV microgrids are seen as a solution to increase the renewable energy penetration rate and accelerate the access to electricity in rural or remote areas, therefore increasing the electrification ratio and simultaneously contributing to the Paris Agreement.

However, the long-term reliability of PV microgrids has been an issue in Indonesia. Due to the shortcomings in the planning [7,8], design [7,9], and operation and maintenance (O\&M) [10,11] phases, several problems emerge. There are a number of PV microgrids funded by MEMR that have a shorter lifetime (approx. 4 years) compared to the typical PV system lifetime (approx. 7 years), which was discovered via interviews with NZMATES [12]. The perceived reason for this was, that the MEMR funds seem to cover only initial investment costs. They include the costs made for design, procurement of materials, construction, and final commissioning, without provisions for the O\&M costs. Consequently, the local government is expected to deal with the O\&M costs, which in most cases were not taken into account. The lack of O\&M can lead to problems with the PV microgrids' sustainability. This is a clear example of a technological issue that was identified as a potential challenge in Part I of this publication, "Te3: lack of OEM standard". Even though there are training activities for the operators in the villages, the training is not sufficient for the local government to be able to operate PV microgrids. As a result, the local operators will need to find technicians or engineers who commonly live or work far away from the microgrid location, resulting in longer downtimes and increased costs.

Many papers discuss the sustainability and reliability of PVs or microgrids. In [13,14], the scholars reported the techno-economic feasibility and sustainability analysis of hybrid microgrids. In $[15,16]$, the authors improve the sustainability of a hybrid energy system 
by using a decentralized multiagent system (MAS) for power management in a hybrid microgrid, which increased efficiency and decreased operational costs altogether. A survey conducted by Energizing Development (Endev) [17] showed that the failure of PV microgrids in Indonesia were dominated by inverter failures and battery failures with an undetermined origin. However, it also showed that lightning strikes are a reoccurring source of failures. To increase sustainability and reliability, in [18-20] the authors proposed a novel modular microgrid architecture and management technique. It enables the optimization of multilayer control, reliability during the dynamic condition, and sustainability under normal and abnormal conditions. Unfortunately, these reports provided limited information about issues in the planning, design, and O\&M phases.

This paper is the continuation of part I in which a multi-tier framework (MTF) has been developed. Part II continues by investigating in more detail the technological challenges during the planning, design, and O\&M phases. Part II does this by focusing on the actual microgrid site conditions including the analysis from the relevant stakeholders. It also includes potential technologies that can improve the sustainability and reliability of PV microgrids.

The main contributions of part II of this paper are as follows:

1. To investigate the actual problems in planning, design, and O\&M phases of PV microgrids in Indonesia including the examples of PV hybrid systems in MMU. The PV hybrid in this paper is the combination between the PV system and diesel generator.

2. To recommend several advanced microgrid technologies as technology outlook for PV microgrids in Indonesia such as microgrid online monitoring system, load forecasting estimation, PV panels degradation, battery state-of-health $(\mathrm{SoH})$ estimation, and maximum energy yield strategies by deploying micro inverters and direct current (DC) optimizers.

The paper is structured as follows: Section 2 discusses microgrids in an Indonesian context based on a literature review, data, and interviews that were performed from PLN, NZMATES, and EnDev. More specifically why PV microgrids are so important for Indonesia, and the problems they are facing. Section 3 describes the technological outlook that can be adopted in PV microgrids in Indonesia to address those issues. Finally, some concluding remarks are made in Section 4.

\section{Research Approach}

The data in this paper were obtained through direct interviews and available data from PLN and NZMATES. PLN is an Indonesian state-owned corporation while NZMATES is a program funded by New Zealand to support the usage of renewable energy in Maluku. The data of the studied PV microgrids have been anonymized, as some details are confidential. Some of the PV microgrids are owned and operated by PLN, while others are funded by MEMR and operated by local communities with the technical assistance provided by NZMATES. The results were compared with a survey from EnDev to get a more complete picture of the microgrid conditions in Indonesia.

\subsection{Indonesia Microgrids}

In Figure 2 a classification scheme is given based on the size of microgrids and their connection to the grid or lack of. In Indonesia, only the larger microgrids seem to have an impact on the energy mix target 2025. Examples of large installations are PV Bontang and Oelpuah (more than $2 \mathrm{MW}$ ), Ulumbu and Matalako geothermal (more than $5 \mathrm{MW}$ ), Lubuk Sao, and Cibareno hydro powers (more than 2.5 MW), and Petapahan dan Damit Hulu biogas plants (more than $1 \mathrm{MW}$ ).

While smaller microgrids have less capacity, thus contributing relatively a small amount to the total renewable energy mix, they however are more suitable to reach isolated areas thus their potentials lie in the increased number of implementations. To increase numbers the Indonesian government has issued a policy to accelerate the electrification of underdeveloped, border, and outlying areas (often referred to as 3T areas). Data from 
the geoportal Ministry of Energy and Mineral Resources (MEMR) Indonesia shows that 714 isolated microgrids have been installed in the 3T areas. Even though the total power generated increased to $30 \mathrm{MW}$, covering around 100,000 households, it is shown that remote microgrids only contribute $0.3 \%$ of the total power generated in isolated microgrids owned by the MEMR.

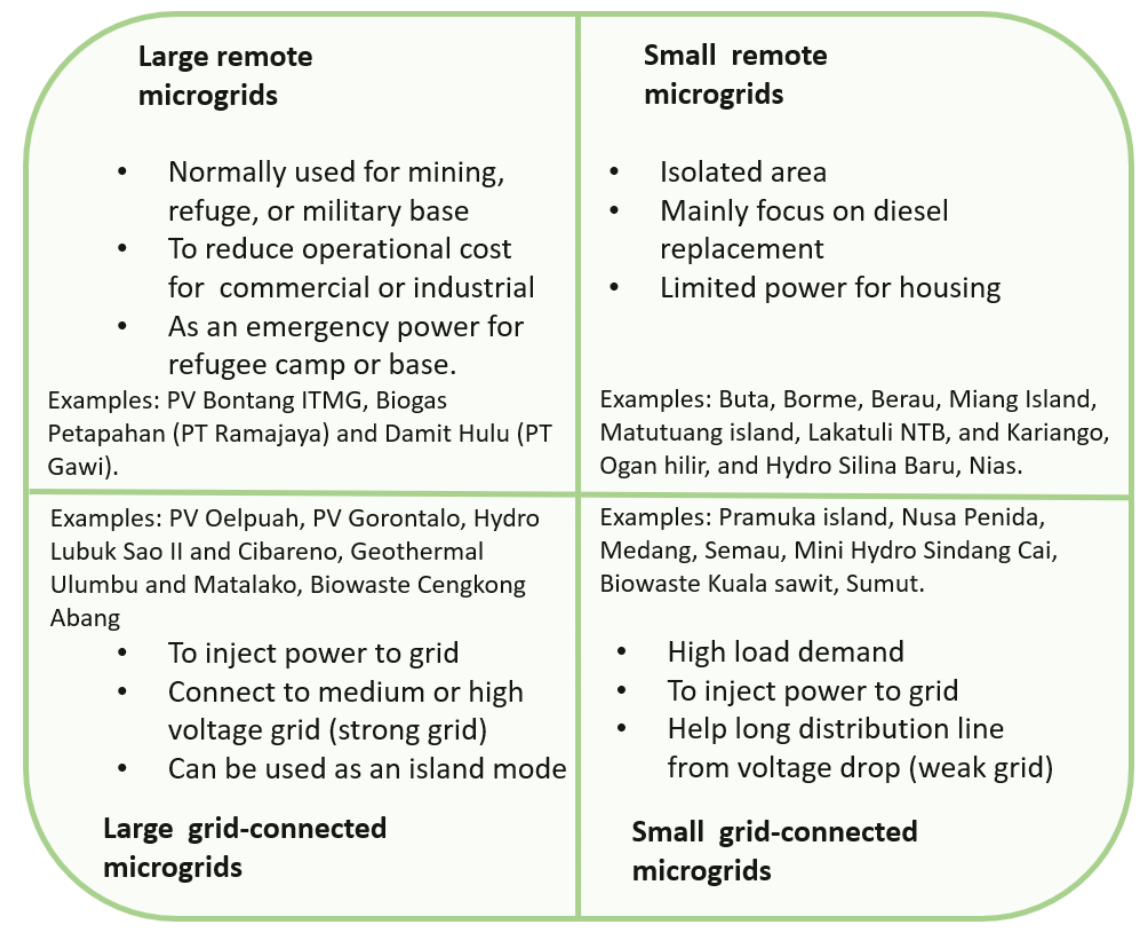

Figure 2. Microgrids classification and main characteristics in Indonesia.

\subsection{The Importance of PV Off-Grid Microgrids}

The extension of the grid faces huge financial and technical barriers when providing or improving energy access to rural areas [21]. These barriers exist due to Indonesia's islanded structure, which makes supplying electricity to the 3T areas difficult. Next to this, the structures should take earthquakes into account, since Indonesia lies on the ring-of-fire which is at the meeting point of the Pacific, the Eurasian, and the Indo-Australia continental plates. These conditions make the development of a super-grid not feasible.

Since the Indonesian government issued some policies on renewable energy, the development of the microgrid has been increasing. However, power quality issues arise. The power quality of solar light in Maluku and North Maluku is low as the solar can only generate energy to light in the afternoon when the irradiation is high enough. Table 1 shows that the power quality disparity occurs in some underdeveloped areas in Indonesia. There are 68 villages and 50 villages in Maluku and North Maluku has access to solar light only which makes them depend on solar irradiation. Another thing is the isolated microgrids funded by MEMR contribute to around 30\% in Maluku, while in North Maluku it is only $18 \%$.

To achieve both mixed renewable energy mix and power quality targets, the PV microgrids can be a solution to increase the power quality and meet the mixed renewable energy target in 2030 as per Figure 3. The PV off-grids can help to improve attributes of energy access (capacity, availability, reliability, quality, and affordability), increase the electrification ratio, reduce the economic gap between rural and urban areas, and simultaneously the PV can increase the renewable energy mix target set by the Indonesian government. Besides that, the PV microgrids are more feasible than the super-grid in the medium term. The Indonesian government has initiated the 'Bright Indonesia Program' to provide energy access by utilizing more solar light as an energy source for the lighting in 2500 villages. 
Table 1. Villages with electricity in Maluku and North Maluku [22-24].

\begin{tabular}{|c|c|c|c|c|c|c|}
\hline \multirow{2}{*}{ No. } & \multirow{2}{*}{ Province } & \multirow{2}{*}{$\begin{array}{c}\text { Total } \\
\text { Villages }\end{array}$} & \multicolumn{3}{|c|}{ \# Villages with Electricity } & \multirow{2}{*}{ Percentage } \\
\hline & & & PLN $^{1}$ & Non-PLN ${ }^{2}$ & Solar Light ${ }^{2}$ & \\
\hline 1. & Maluku & 1233 & 871 & 294 & 68 & $100.00 \%$ \\
\hline 2. & North Maluku & 1180 & 967 & 163 & 50 & $100.00 \%$ \\
\hline
\end{tabular}

${ }^{1}$ PLN $=$ Perusahaan Listrik Negara (State-owned Utility Company). ${ }^{2}$ Non-PLN and Solar Light $=$ The villages with electricity access from the government, private sector, or the community.

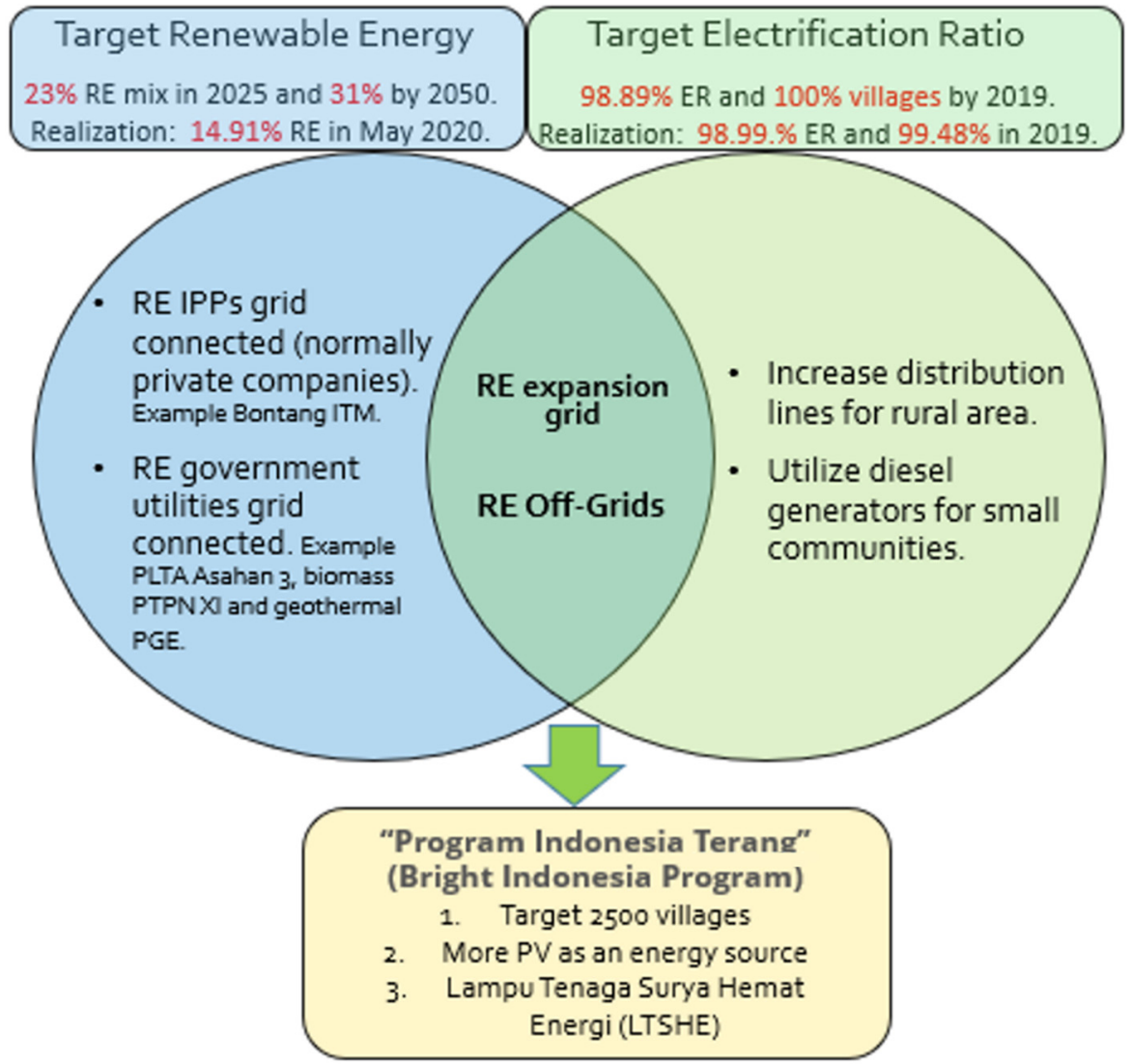

Figure 3. The Indonesian government goals and how PV islanded contribute to both goals.

\subsection{Challenge of PV Microgrids in Indonesia}

In part I: scaling sustainability challenge and a technology outlook, the framework has been developed and to link the challenge to the respective phases like planning, design, and operation and maintenance $(\mathrm{O} \& \mathrm{M})$ phases. This sub-section explains the actual condition of PV sites in Indonesia. The cases in each phase are investigated and explored to understand the real condition and how to mitigate those issues. The suggestions are provided to extend the PVs site lifetime.

Table 2 shows all 15 PV microgrids sites in MMU. The problems are identified with respect to the planning, design, and O\&M phases and will be elaborated on in this paper. The first set of challenges (as per in framework in part I) that was identified via an interview with PLN and NZMATES is related to the planning phase. The load characterization, load forecast, and PV diesel generator sizing are investigated in the following sub-section. The second set of challenges is the design phase in which the PV system should be designed with a long lifetime and low losses. This includes the design architecture, automatic switch to simplify the operator works, and battery system design. The PV hybrid architecture and PV synchronization with the diesel generators are taken into account in this design phase. The third and last phase that is discussed in this paper is the O\&M phase. The 
O\&M activities are important to keep PV microgrids reliable and sustainable. Daily and monthly monitoring to detect the degradation and failure are needed to keep PV microgrids continuously generating power and delivering it to the community. Spare part availability and battery string condition are also discussed in the O\&M phase.

Table 2. Data of PV Microgrids in Maluku and North Maluku [23,24].

\begin{tabular}{|c|c|c|c|c|c|c|c|c|c|}
\hline $\begin{array}{l}\text { PV Desig- } \\
\text { nator }\end{array}$ & $\begin{array}{c}\text { Year of } \\
\text { Operation }\end{array}$ & Location & $\begin{array}{c}\text { Funded } \\
\text { by }\end{array}$ & Type & $\begin{array}{l}\text { PV Desig- } \\
\text { nator }\end{array}$ & $\begin{array}{c}\text { Year of } \\
\text { Operation }\end{array}$ & Location & $\begin{array}{c}\text { Funded } \\
\text { by }\end{array}$ & Type \\
\hline Site 1 & 4 & Ambon & PLN & Off-grid & Site 9 & 3 & Saumlaki & MEMR & Hybrid \\
\hline Site 2 & 8 & Ambon & PLN & Off-grid & Site 10 & 3 & Tual & PLN & Hybrid \\
\hline Site 3 & 3 & Ambon & PLN & Off-grid & Site 11 & 2 & Tual & MEMR & On-grid \\
\hline Site 4 & 3 & Masohi & PLN & Off-grid & Site 12 & 3 & Saumlaki & MEMR & On-grid \\
\hline Site 5 & 5 & Masohi & PLN & Off-grid & Site 13 & 6 & Tobelo & PLN & Hybrid \\
\hline Site 6 & 5 & Masohi & PLN & Off-grid & Site 14 & 2 & Saumlaki & PLN & Hybrid \\
\hline Site 7 & 3 & Tual & PLN & Hybrid & Site 15 & 5 & Tobelo & MEMR & On-grid \\
\hline Site 8 & 4 & Tual & PLN & Hybrid & & & & & \\
\hline
\end{tabular}

\subsubsection{Planning Phase}

PV hybrid microgrid site 1 is given an example of poor load forecasting. The peak load was $3.5 \mathrm{~kW}$ in 2016, but since the energy access boosted the local economy, the peak load increased to $6.5 \mathrm{~kW}$ in 2019 as seen in Figure 4. The significantly increased load was a burden to the battery. Due to the high discharging rate, 16 out of 120 batteries were damaged resulting in an inadequate battery voltage for charging. Another consequence was that the diesel generator needed to operate longer than design anticipated which gave an impact on the operational costs (the cost of diesel fuel). This problem clearly shows that economic growth impact needs to be accounted for in proper load forecasting (capacity and availability MTF), which is already recommended in [8,14]. The battery bank should be upgraded, and the damaged batteries need to be replaced promptly to accommodate the load demand, otherwise, the remaining batteries can also degrade fast. As the PV power cannot cover the load for a full day, it can be used for a certain time like in the afternoon only. In the late evening or early morning, an additional diesel generator is needed. Another solution is by installing an additional PV system that can accommodate the load demand.

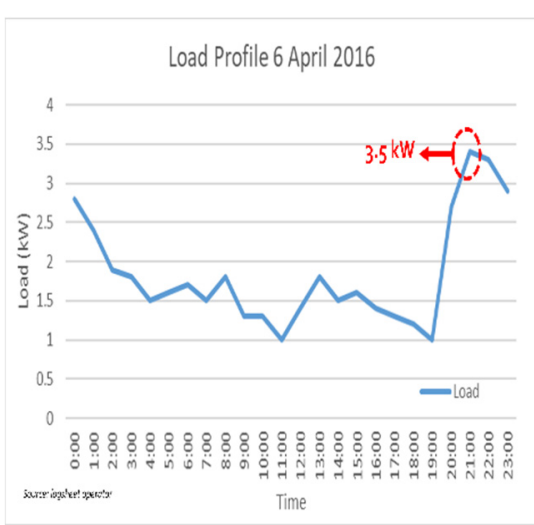

(a)

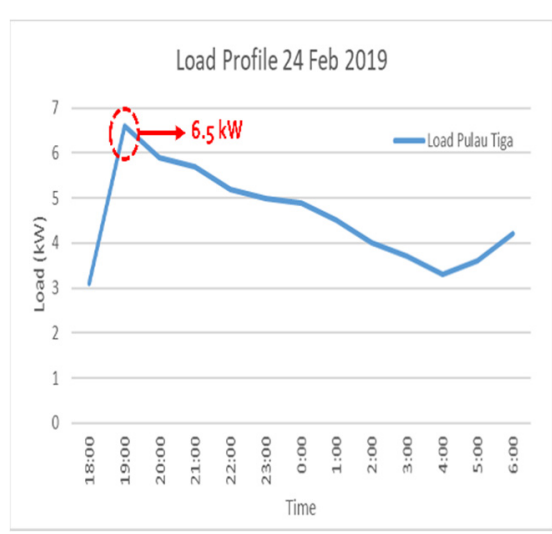

(b)

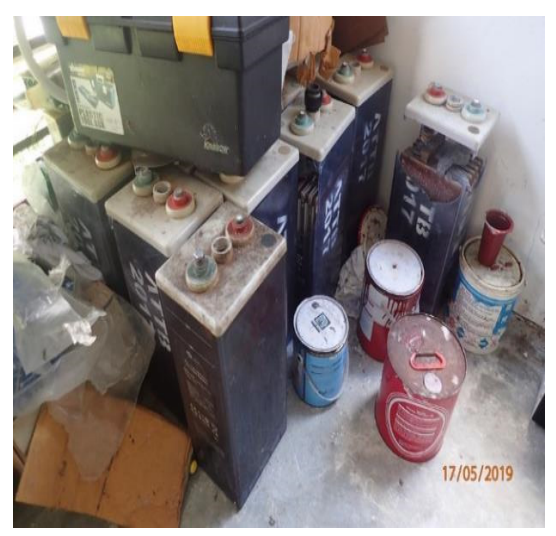

(c)

Figure 4. Load profile PV microgrid site 1 in: (a) 2016; (b) 2019; (c) damaged batteries.

Figure 5 shows the condition of PV hybrid microgrid site 12. The microgrid has not been operating since 2019 even though the PV system was in a good condition. As the 
PV system was connected to the diesel generator as a hybrid, it made the specific fuel consumption (SFC) of the diesel generator not efficient. The PV inverter power was $100 \mathrm{~kW}$ while the nominal daily load was around $200 \mathrm{~kW}$. It is known that the SFC diesel generator is typically optimum at $75-80 \%$ of the nominal rated capacity but degrades very rapidly when the diesel generator is operated below $40 \%$ of its rated capacity (affordability MTF). The PV system could operate in the peak shaving only, where one or two generators can be turned off, thus keeping them operating above the $40 \%$ threshold. Another option is to cover $20-30 \%$ of the load demand by the PV installation, the remaining produced power can be used to charge a battery.

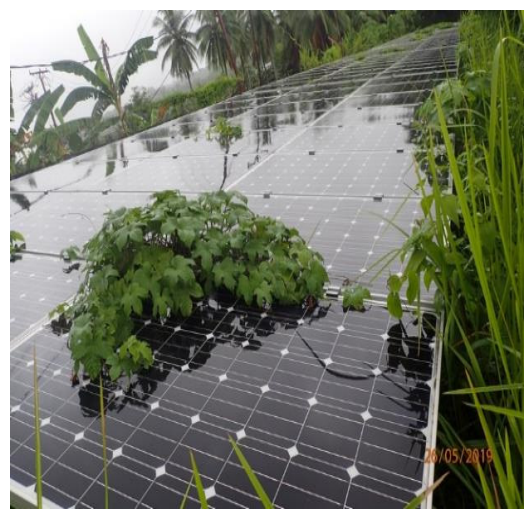

(a)

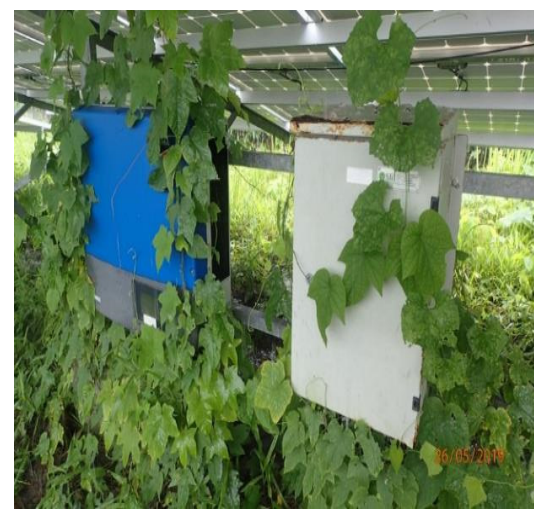

(b)

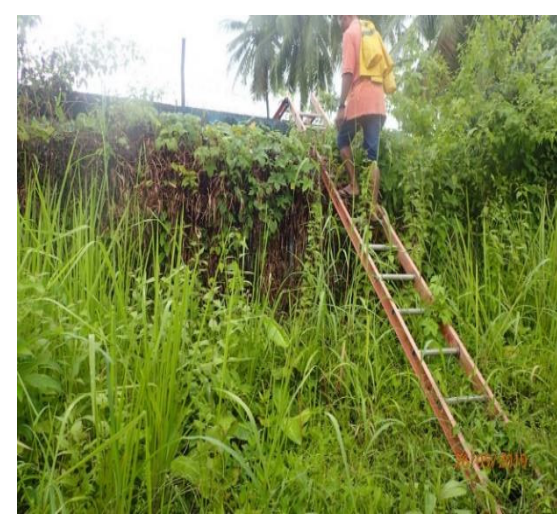

(c)

Figure 5. Abandoned PV site 12: (a) PV panels; (b) PV's junction boxes; (c) powerhouse.

\subsubsection{Design Phase}

The case of PV hybrid site 14 is an example of a typical design phase problem as seen in Figure 6. The $100 \mathrm{kWp}$ PV-diesel site 14 was designed for the isolated load condition, of which in the afternoon, the PV will cover the load, and in the evening, the load will be covered by the diesel generator. The operator needed to manually switch between the PV system and diesel generators. Due to this inefficient way of operation, the PV system were not used anymore (availability and reliability MTF). As a consequence, the inverter, combiner boxes, and powerhouse slowly decayed over time. An automated switch between operating conditions would circumvent this type of design flaw. The design phase needs to consider the existing diesel generator and how to interconnect the PV system with a minimum amount of manual labor, i.e., in the case of a hybrid microgrid, the operator should not need to go to the PV site, except for maintenance.

The system architectures of sites 1 and 8 are different with respect to the battery charger as shown in Figure 7. In the case of site 8, each battery system has its own battery charger, which is a bi-directional inverter, while PV site 1 uses the PV inverters as a battery charger. In [25] it was shown that if the demand load is more than $80 \%$ of the power generated by the $\mathrm{PV}$, the layout of site 8 has the highest efficiency. If the load is less than $80 \%$ of the power generated and the excess energy charges the battery, site 3 will have the highest efficiency. Unfortunately, there is no site-specific data available to verify these expectations. 


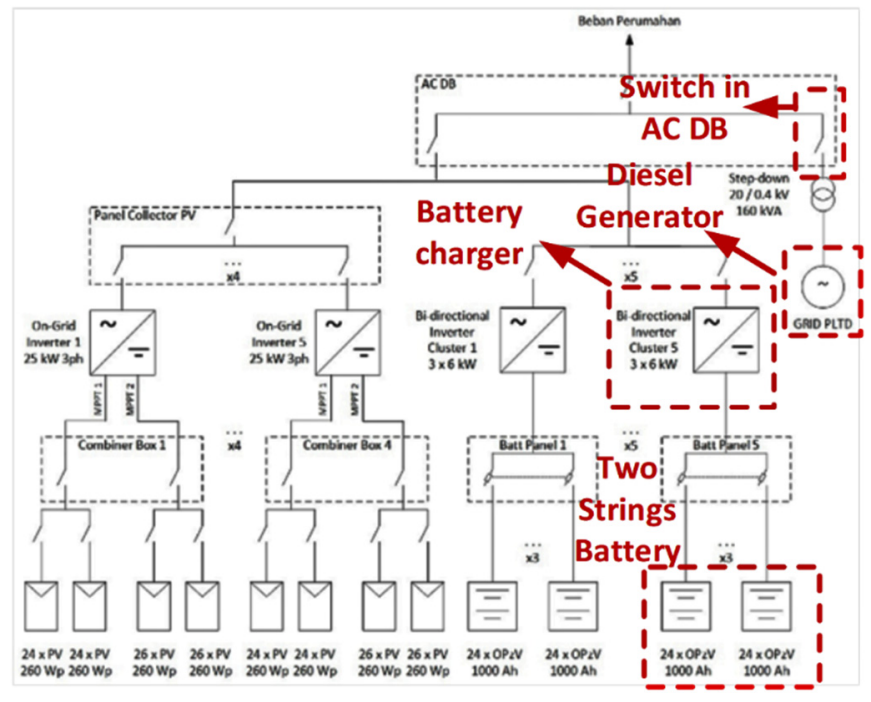

(a)

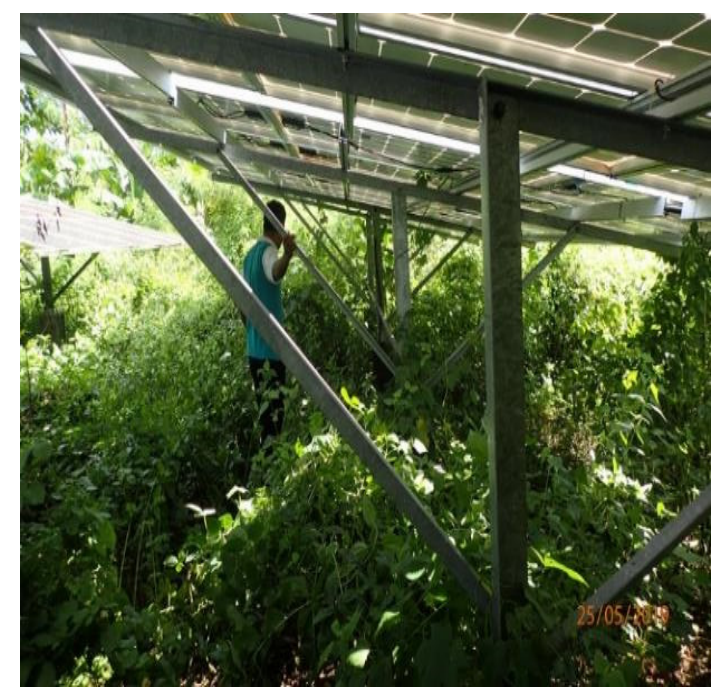

(b)

Figure 6. PV site 14: (a) single line diagram; (b) abandoned PV facility.

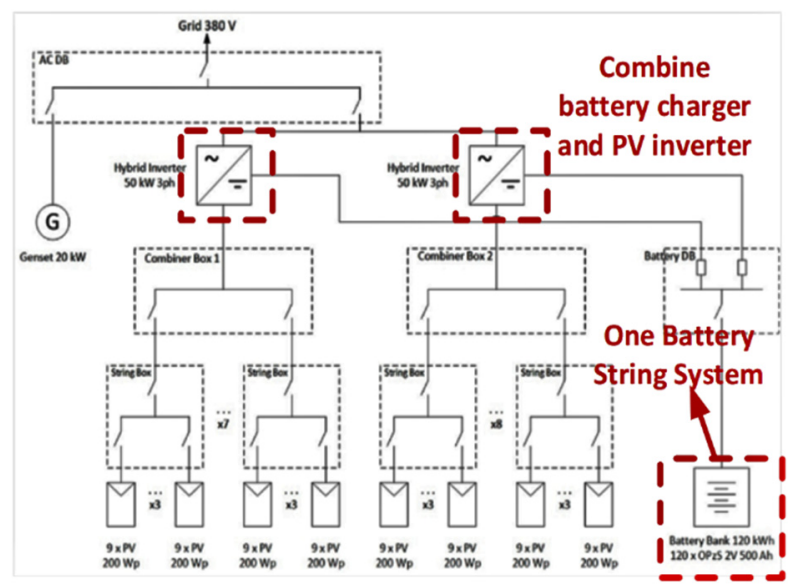

(a)

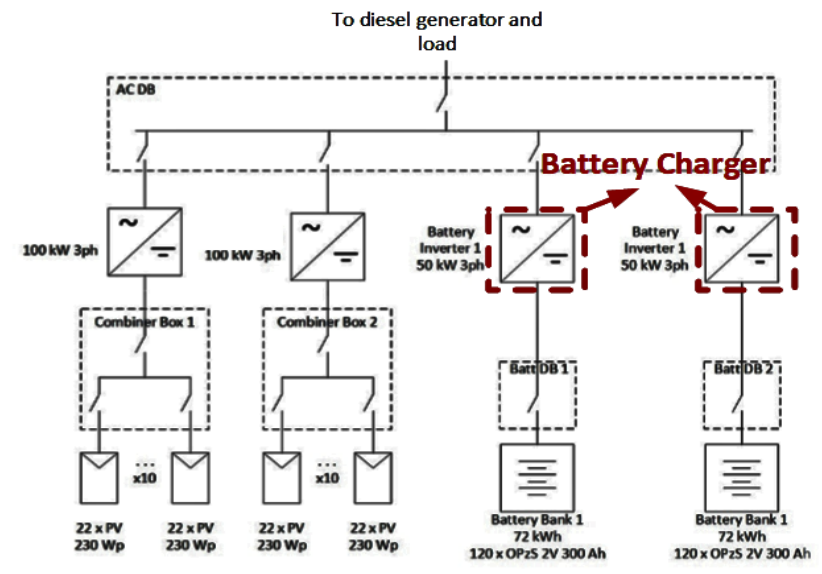

(b)

Figure 7. Single line diagram; (a) PV site 1; (b) PV site 8.

The battery was identified as the second highest failing component $[12,23,24]$ after the PV's inverter and thus requires to be well designed and maintained. The two parallel strings in Figure 7a will be suitable to accommodate the partial operation (reliability MTF) of the battery during the offline inspection and replacement activities (see examples in O\&M). Air conditioning is mandatory for designing a battery room (if the ambient temperature is higher than manufacturer's recommendation) as per IEEE Std. 937-2019 as the battery life has a strong relationship to temperature and humidity. As seen in Figure 8, there is no temperature control in PV site 1 and only an exhaust fan in the battery room of PV site 14. As per IEEE std. 1561-2019, the lifetime of battery vented lead-acid (VLA) batteries will decrease about $50 \%$ for every $10^{\circ} \mathrm{C}$ increments and $8.3^{\circ} \mathrm{C}$ for the valve-regulated lead acid (VRLA) batteries in permanent temperature operation over $25^{\circ} \mathrm{C}$ (availability and reliability MTF). 


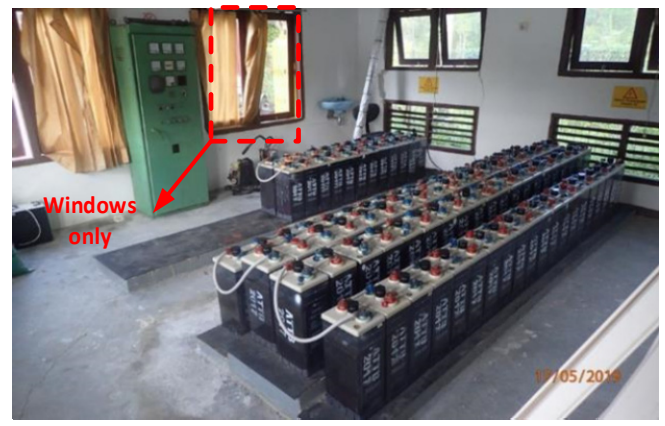

(a)

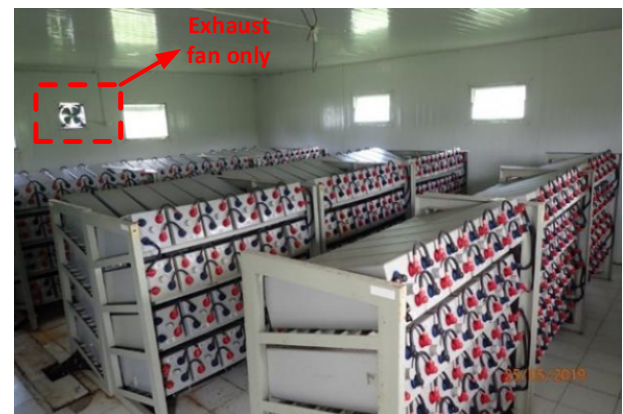

(b)

Figure 8. Battery rooms; (a) PV site 1; (b) PV site 14.

\subsubsection{Operation and Maintenance}

Site 7 is a PV hybrid system, combining a $200 \mathrm{kWp}$ PV capacity with a diesel generator of $880 \mathrm{~kW}$. According to the load demand in that area, in the morning the load required approximately $650 \mathrm{~kW}$ and in the evening at the most $850 \mathrm{~kW}$. Based on Figure 9 provided by PLN, in 2014, the energy generated from the PV system was around $550 \mathrm{kWh} /$ day, but in 2015, this decreased to a maximum of $325 \mathrm{kWh} /$ day. In Indonesia, the dry season is from April to October while the rainy season is then from November to March. Overall, the weather in either April or May will not differ that much. In this case, comparing the maximum of energy generated those were occurring one year apart can indicate the PV performance. By considering the peak values instead of averages, the data is not influenced by temporary fluctuations that are for instance caused by inverter restart issues or string voltage problems. During a year of operation, PV site 7 was degraded by more than $40 \%$. This case shows that the O\&M can be a crucial point to keep the reliability and availability of PV site 7. The battery ( $384 \mathrm{kWh} / \mathrm{OPzS}$ Shoto GFX-800 Ah (240 pcs)) system voltage was around $366 \mathrm{~V}$, which is lower than the rated battery system voltage which is in the range of $420-480 \mathrm{~V}$ (in any state-of-charge level) as per in Figure 10. Further battery inspection needs to be conducted to decide which battery needs to be replaced or not. Through inspection, it was found that the PV modules were damaged, and the combiner boxes were rusty and corroded. Proper maintenance as per IEEE Std. 458-2020 could have avoided such a degradation.

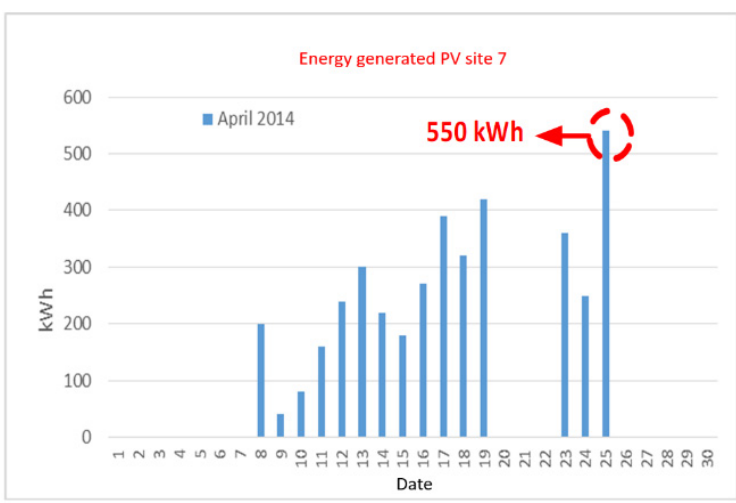

(a)

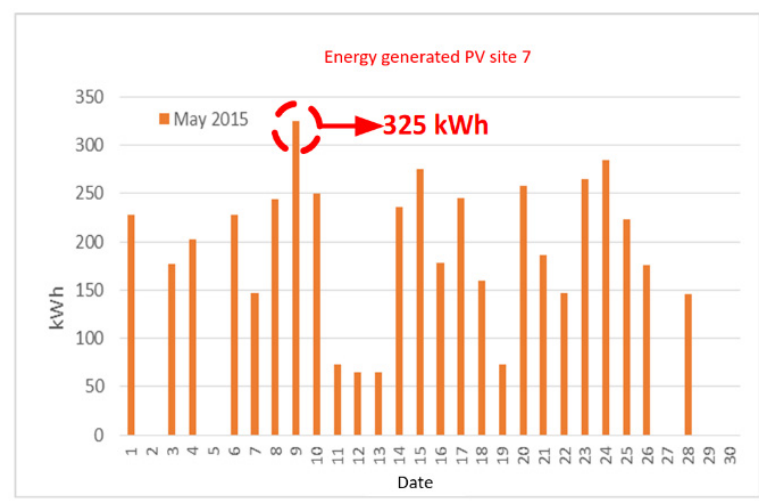

(b)

Figure 9. (a) Energy generated in PV site 7 in; (a) 2014; (b) 2015.

Sites 1 and 7 are examples of battery maintenance and design problem. The single line diagrams (SLDs) can be seen in Figures 7a and 11. It shows that there is only one battery string, which will disrupt the operation (reliability MTF) of the system during battery maintenance or replacement. The IEEE Std. 1561-2019 recommends applying two parallel strings of batteries for redundancy in case of maintenance. The second string provides at least some storage for continued operation as per Figure 6a. Internal and ambient 
temperature measurement, battery pack and cell voltage measurement, and electrolyte level visual check are also recommended for the maintenance check according to IEEE Std. $1561-2019$

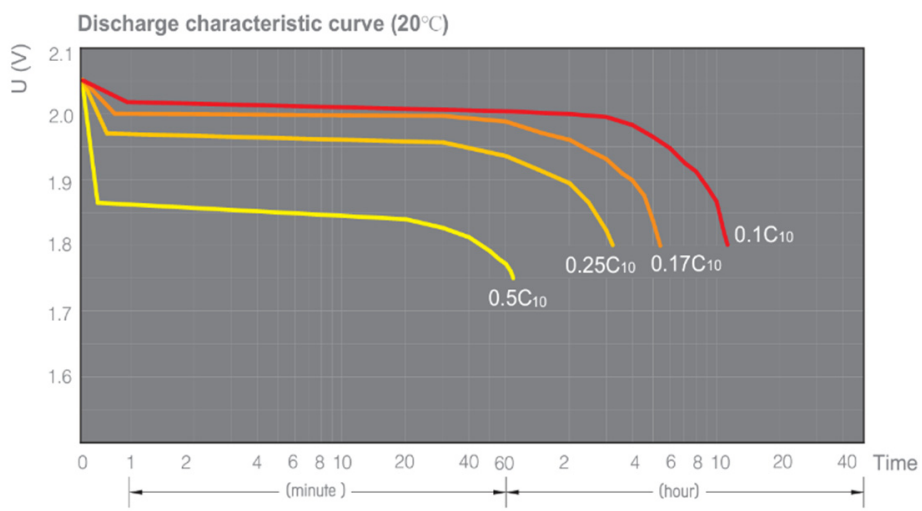

Figure 10. Standard battery voltage characteristic in PV site 7 [26].

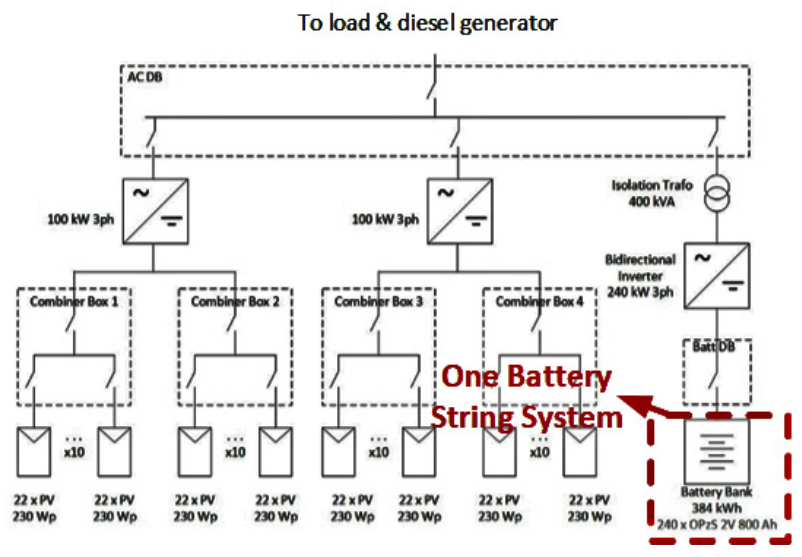

Figure 11. Single line diagram at PV site 7.

Site 13 has a $600 \mathrm{kWp}$ PV installation which is connected to a private diesel generator of $2 \mathrm{MW}$ and a PLN owned diesel generator of $2.3 \mathrm{MW}$ (standby mode). PV site 13 has operated for 6 years, but due to a battery charger problem, it stopped working. A component failure occurred in the battery charger; thus, the battery system was out of order. The manufacturer of the battery charger was permanently closed; therefore, a replacement was not an option. When the PV was operating in conjunction with the diesel generator without any energy buffering, the fluctuated power created a problem for the diesel generator. Therefore, the operator turned off the PV installation (quality MTF).

The best maintenance of the PV inverters and battery charger would be based on the manufacturer's standards (Table 3), but how corrosive the location, ambient temperature, and humidity should be taken into consideration as discussed in site 13. Availability of spare parts are the crucial point to ensure the operation of the PV system, especially for sensitive equipment like IGBT inverter and battery modules. For example, PV site 2 was not in operation due to IGBT failure, and PV site 3 was not operational because of battery failure (480 kWh/OPzS FIAMM LM 1000 ah (120 pcs)) with the actual voltage is $112 \mathrm{~V}$ only, which is lower than the rated battery system voltage in the range of 192-240 V (reliability MTF) as per Figure 12. 
Table 3. Matrix of the PV systems component conditions [23,24].

\begin{tabular}{|c|c|c|c|c|c|c|c|}
\hline \multirow{2}{*}{$\begin{array}{l}\text { PV } \\
\text { Designator }\end{array}$} & \multirow{2}{*}{$\begin{array}{l}\text { First Component } \\
\text { Failure }\end{array}$} & \multicolumn{6}{|c|}{$\begin{array}{l}\text { Impact to the Other Components } \\
\text { ( } \checkmark=\text { in Good Condition; } x=\text { Not in Good Condition; } ?=\text { no Information) }\end{array}$} \\
\hline & & Inverter & Battery & $\begin{array}{l}\text { Battery } \\
\text { Charger }\end{array}$ & PV Panel & $\begin{array}{l}\text { Combiner } \\
\text { Boxes }\end{array}$ & $\begin{array}{c}\text { Local } \\
\text { Internet }\end{array}$ \\
\hline Site 1 & Battery & $\checkmark$ & - & $\checkmark$ & $x$ & $\checkmark$ & $\mathrm{n} / \mathrm{a}$ \\
\hline Site 2 & IGBT Inverter & - & $\mathrm{n} / \mathrm{a}$ & $\mathrm{n} / \mathrm{a}$ & $x$ & $x$ & $x$ \\
\hline Site 3 & Battery & $x$ & - & $x$ & $x$ & $x$ & $\mathrm{n} / \mathrm{a}$ \\
\hline Site 7 & Battery & $\checkmark$ & - & $?$ & $x$ & $x$ & $\checkmark$ \\
\hline Site 8 & Inverter & - & $\checkmark$ & $\checkmark$ & $x$ & $x$ & $\mathrm{n} / \mathrm{a}$ \\
\hline Site 12 & $\begin{array}{c}\text { See 2.3.1 Planning } \\
\text { Phase }\end{array}$ & $?$ & $?$ & $?$ & $x$ & $x$ & $x$ \\
\hline Site 14 & $\begin{array}{c}\text { See 2.3.2 Design } \\
\text { Phase }\end{array}$ & $\checkmark$ & $\checkmark$ & $\checkmark$ & $\checkmark$ & $x$ & $x$ \\
\hline
\end{tabular}

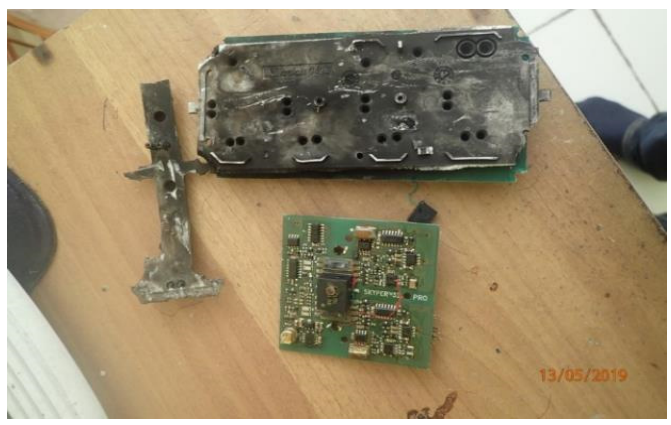

(a)

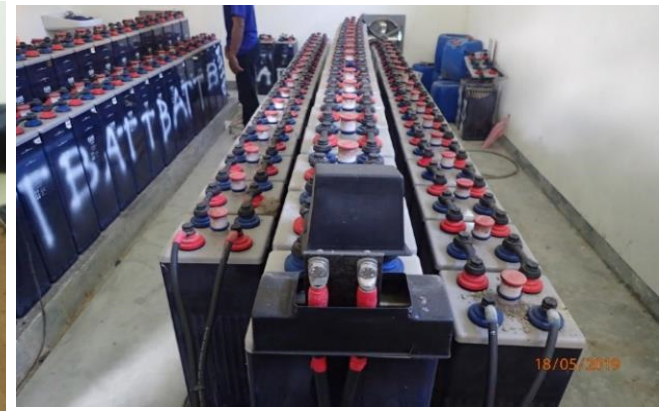

(b)

Figure 12. (a) IGBT failure in PV site 2 (b) Battery failure in PV site 3.

\section{Technology Recommendations}

This section focuses on the technology recommendation to ensure the reliability and sustainability of the PV microgrids in Indonesia. The considered technology outlook are remote monitoring systems, battery and PV lifetime estimation, load forecasting, and the different type of PV inverters are presented.

\subsection{Online Monitoring Solution}

In the roadmap SCADA PLN MMU 2020-2024, PLN Maluku is planning to deploy online control and monitoring system for the grid in the Maluku area. However, the roadmap does not show an online monitoring focus on PV systems. The roadmap SCADA PLN MMU is focused on switching equipment (load break switches, reclosers, and circuit breakers) for controlling, and cubicles only for monitoring. There are a lot of aspects that can be monitored such as PV panel conditions, battery performance, and power generated from PV systems which can extend the PV's lifetime and increase power quality. In addition, the online monitoring system provides real-time information and can reduce the O\&M cost such as reducing the operator's cost and increasing the power quality by estimating the PV's and battery's lifetime.

Figure 13 shows a typical monitoring architecture of PV systems. The current, voltage, power, and energy are the main data to be monitored, but due to the technology development, the batteries and the PV panels lifetime can also be monitored as per issues in sites 3, 7, and 13. The PV and battery's maintenances can be scheduled based on the online monitoring systems and the O\&M costs can be reduced. The data from PV, battery management systems (BMS), inverters, energy meters, and relays are collected in the data 
acquisition unit. Then the data can be delivered to the local monitoring system by cable or Wi-Fi communication. To increase data accessibility, the data can be uploaded to the internet cloud system and monitored via a mobile phone, tablet, or personal computer (PC) through the internet. Few online monitoring companies provide these services like 60 hertz, canopy power, and ferntech. Furthermore, in the high microgrid penetration, ref [27] proposed the cloud-based and hybrid wireless mesh communication framework for bilevel, nested, distributed optimization of networked clusters of microgrids. This method introduced the optimization framework communication in the high microgrid systems as per IEC 61,850 to achieve a certain delay performance and guaranteed optimization convergence. To reduce the cost, ref [28] proposed the decentralized smart grid using the 'edge of the network' to reduce the monitoring systems' cost. The nanogenerators as self-powered sensors can be added to monitor the PV systems with low losses [29,30]. This cloud-based system and 'edge of the network' can be adopted in sites 5 and 14 . The distributed optimization can be used in site 5 , therefore, there is optimum communication between PV, battery, and diesel generator to reduce the diesel generator's SFC. In site 14, the layer communication can link the operation of PV and diesel generator, thus, the switch breaker can be operated automatically.

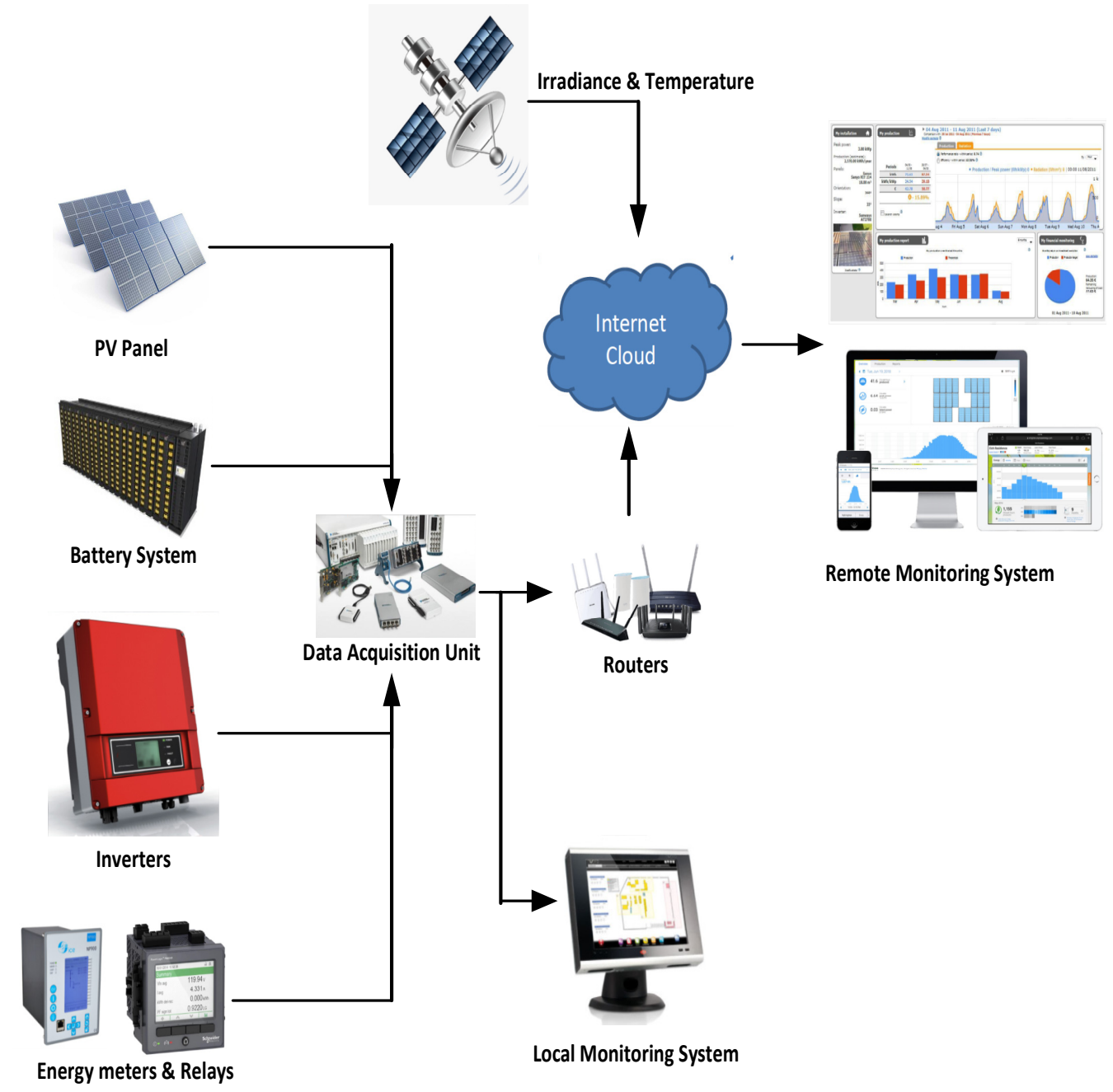

Figure 13. The typical online monitoring system of PV microgrids.

\subsection{PV and Battery Lifetime Estimation}

The simple way to estimate the PV panel condition is to measure the voltage and current output and visual check of the PV panels, but this conventional method has a wide range of error since the irradiance and temperature affect the current and voltage, while a 
visual check requires more time to look into the cracks and black spots in PV panels. To reduce the visual checking time and to predict the PV panel degradation, machine learning (ML) algorithms could be implemented [31,32]. In [32], the authors proposed unmanned aerial vehicles (UAVs) with infrared (IR) and visible images in the red-green-blue (RGB) channel techniques to estimate the RUL of the PV modules as per Figure 14. The drone will irradiate the PV panels and evaluate the thermographic behavior of the PV modules. The images will be processed by a decision support system to estimate the degradation of the PV panels. This PV panel's lifetime estimation can solve the site 7 issue and help the operator to decide what treatment or maintenance can be performed to solve that issue. The operator can then decide on a replacement schedule of PV panels. This technology can reduce the O\&M costs and keep the PV system continuously generating energy.
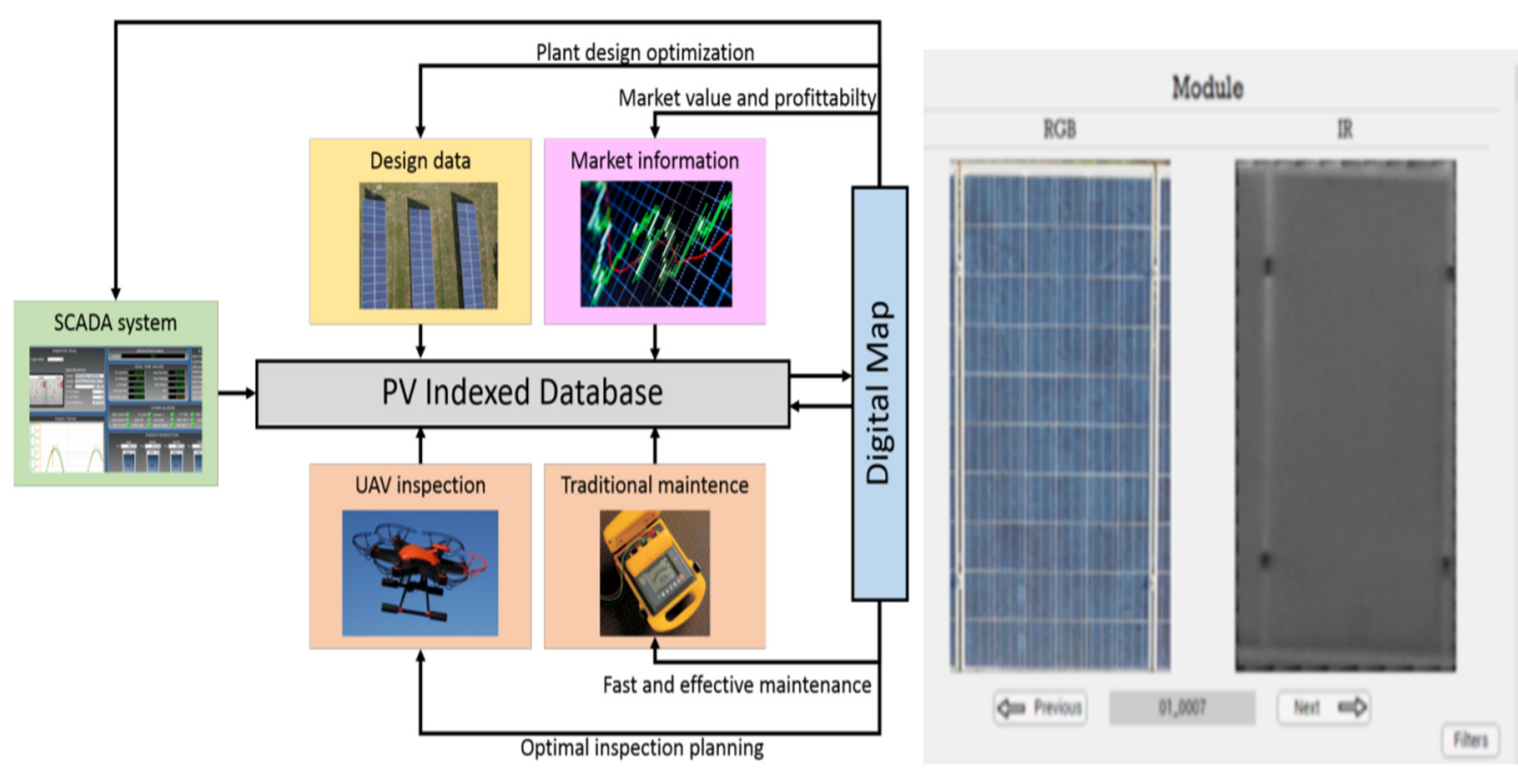

Figure 14. Proposed PV panel monitoring systems based on unmanned aerial vehicles [32].

For the energy storage system (ESS), the authors in [33] showed that lithium-ion battery has a higher cycle, lower maintenance, and is more efficient compared to the lead-acid battery, although it is more expensive. BMS is the technology to keep the batteries are in a good condition by using cell balancing, under and over-voltage protection and temperature management. Another battery storage technology is the battery RUL estimation. There are two types of battery RUL estimation. The first is the offline measurement The battery must be unplugged from the system before the parameter related to the battery RUL are measured. The second is the battery RUL online measurement where the battery is still plugged into the system. The advanced technology for the battery RUL measurement is the electrochemical impedance measurement (EIS). The EIS injects a ripple current to the battery, and since the battery has a unique characteristic impedance, the battery output terminal voltage will respond to the current and the battery internal impedance can be obtained $[34,35]$. The impedance of the battery has a strong relationship to the battery RUL which is typically the battery's internal impedance will increase due to the cycle time as seen in Figure 15. Sites 1, 7, and 14 can use the EIS method to estimate the battery lifetime and decide further action to mitigate the damage to the battery. 


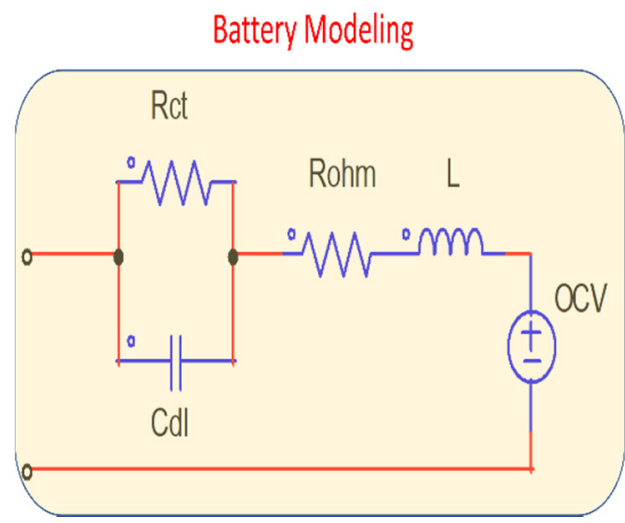

(a)

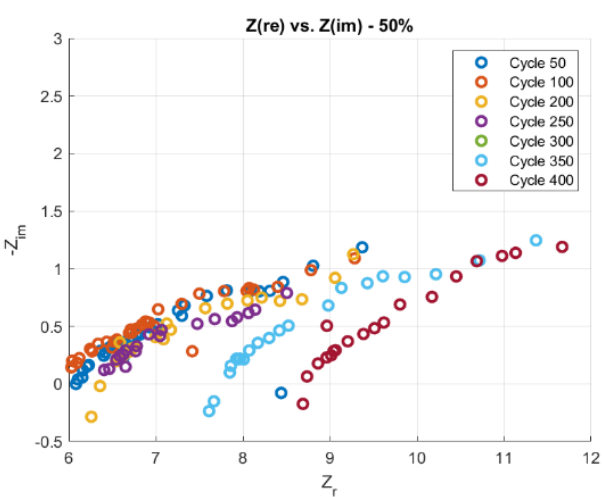

(b)

Figure 15. (a) Battery impedance parameter; (b) battery impedance over the cycle time.

\subsection{Load Forecasting}

Load forecasting strategies are part of the planning issues which need to be well estimated as a basis of PV, diesel generator, and battery sizing. The medium-term load forecast (MTLF) and long-time load forecast (LTLF) need to be accurately estimated at the beginning of the design phase since this estimation will affect the expansion area, spare, and space in the substation cubicles, inverter-diesel generator synchronization, and automatic switch. While the short-time load forecast (STLF) needs to be calculated for the source load balancing and the energy fluctuation in the battery system. Different methods can be applied to estimate the load depending on the model identification and load characterization. Normally MTLF and LTLF use the trend analysis, end-use analysis, econometric analysis, neural network technique, and multiple linear regression, while STLF is calculated by fitting data, extrapolation, and linear regression. The neural network (NN) method is the famous strategy to provide high accuracy for the long-term estimation, but the training data are needed and updated to increase the accuracy. While support vector machine (SVM) uses only a subset of a dataset as training data and makes a faster estimation, but in general, the accuracy of SVM is lower than NN. These LTLF methods estimate the load forecast from few years up to 20 years and can be applied to site 1 in the planning phase to mitigate the poor load forecast. When the load growth is higher than the energy generated from the existing PV microgrid, additional PV panels can be installed depending on the rating of the batteries, inverters, panels, and other supporting equipment. While, when the load is lower than the energy generated from PV, the PV can help another village to supply electricity if the distance is considered taken into account. Table 4 shows the references for the load forecasting strategies.

Table 4. Comparison of load forecasting methods.

\begin{tabular}{ccccc}
\hline Purpose & Model & Year & $\begin{array}{c}\text { Mean Absolute } \\
\text { Percentage Error }\end{array}$ & Location \\
\hline STLF & FS (IT2FS) [36] & 2011 & $1.034 \%$ & Indonesia \\
\hline STLF & LR (WOA-DWT-MLR) [37] & 2019 & $1.30 \%$ & Taiwan \\
\hline STLF & SOM-K ANN [38] & 2014 & $2.71 \%$ & Spain \\
\hline MTLF & SVM [39] & 2018 & $0.196 \%$ & China \\
\hline MTLF & SVP + SVB [40] & 2013 & $7.00 \%$ & No data \\
\hline LTLF & RNN with hybrid GRU [41] & 2020 & $6.54 \%$ & No data \\
\hline
\end{tabular}

For example, in site 1, the LTLF based on the bottom-up feature such as feeder load composition, large customer net load change, distributed energy resources adop- 
tion growth, and the previous-year peak demand can be calculated. The feeder load consumption and the residential and commercial peak load percentage can be estimated by Equations (1) and (3). While the distributed energy resources can be estimated by Equation (2) [41].

$$
\begin{gathered}
R=\frac{\sum_{i=1}^{n} L_{i}^{R}}{p_{f}} \times 100 \% ; C=\frac{\sum_{i=1}^{n} L_{i}^{C}}{p_{f}} \times 100 \% ; I=1-R-C \\
D=\frac{\sum_{i=1}^{p} D_{i}}{p} ; E=\frac{\sum_{i=1}^{p} E_{i}}{p} \\
R_{v}=\frac{\sum_{i=1}^{p} D_{i} P_{i}}{p P_{v}} \times 100 \% ; C_{v}=\frac{\sum_{i=1}^{p} C_{i} P_{i}}{p P_{v}} \times 100 \% ;
\end{gathered}
$$

\subsection{PV Inverters Technology}

Based on the data from PLN Maluku, the architecture of the PV inverters is always the string inverters architecture. To improve the lifetime of the PV systems due to the inverter single point of failure, it can be converted to multiple points of failure by using micro-inverter technology. Moreover, the micro-inverter increases the energy yield due to the individual maximum power point tracking (MPPT) in each panel which can prevent the partial shading impact to the string inverters [42]. A micro-inverter is a small inverter attached underneath the PV panels to operate the panel individually. The benefit of the micro-inverter is to operate MPPT separately in each PV panel. Therefore, when one panel has partial shading, only this particular panel operates below maximum power, while the other PV panels operate in the maximum tracking point. Additionally, the micro-inverter has a unique serial number which makes it easy to monitor each PV panel's power generation and identify the degradation of the individual PV panel. The DC optimizer [43] provides the same benefit as the micro-inverter for the battery monitoring, but the DC optimizer does not increase the single point of the failure condition. Table 5 shows the comparison of the string inverters, micro-inverters, and DC optimizers with

\begin{tabular}{|c|c|c|c|c|c|c|}
\hline Type & Company & Model & Power (kW) & Efficiency & $\begin{array}{l}\text { Multiple Points of } \\
\text { Failure }\end{array}$ & $\begin{array}{c}\text { Individual PV } \\
\text { Panel Monitoring }\end{array}$ \\
\hline $\begin{array}{l}\text { String Inverter } \\
\text { (Site 2) }\end{array}$ & Sungrow & SG100K3 & 100 & $96.4 \%$ & $x$ & $x$ \\
\hline $\begin{array}{l}\text { String Inverter } \\
\quad \text { (Site 8) }\end{array}$ & $\begin{array}{l}\text { Solar power } \\
\text { solution }\end{array}$ & SR5KTLA1 & 50 & $96.8 \%$ & $x$ & $x$ \\
\hline \multirow{2}{*}{ Microinverters } & Enphase & IQ 7X & 0.32 & $97.5 \%$ & $\checkmark$ & $\checkmark$ \\
\hline & Chilicon Power & CP-250E & 0.29 & $96 \%$ & $\checkmark$ & $\checkmark$ \\
\hline \multirow{2}{*}{$\begin{array}{l}\text { DC Optimizers/ } \\
\text { Power Optimizers }\end{array}$} & SolarEdge & P300 & 0.30 & $99.5 \%$ & $x$ & $\checkmark$ \\
\hline & Huawei & SUN2000 & $0.45 \%$ & $99.5 \%$ & $x$ & $\checkmark$ \\
\hline
\end{tabular}
different companies.

Table 5. Comparison of selected string inverters, micro-inverters, and DC optimizers.

\section{Conclusions}

The second part of the paper series has analyzed the potential technical challenges that were identified in the first part of the series. During the development of the framework, four distinct challenges were identified. First, the lack of practical and technical knowledge and inadequate preliminary survey were observed. Second, there was a lack of local skilled personnel. Third, the lack of O\&M standards and lastly issues were identified regarding Power Quality. Which are high-level descriptions, that have been elaborated on in this paper's part II. The PV microgrid conditions in Indonesia were investigated by data 
provided by the relevant stakeholders such as PLN, NZMATES, and EnDev. Not all data was quantifiable, as some of it was provided via interviews. Although it sometimes leads to qualitative analysis, the actual problems related to the PV planning, design, and O\&M phases were investigated.

It can be concluded that during the planning phase, load characterization didn't anticipate (heavy) growth patterns thus PV and battery were undersized. Estimation strategies have to be implemented to ensure the correct sizing.

During the design phase, it was observed that local climate was often not taken into account. Batteries should be in a steady low-temperature environment but were found in warm rooms, thus reducing the lifetime considerably. Which attributes to the overall short lifetime of the microgrid systems under investigation.

Using a proper O\&M standard or protocol, the degradation of the batteries could be taken into account, thus ensuring high energy generation. Which gives in turn rise to a faster return on investment. It was also seen that the use of "near" end-of-life products, increased the difficulty to perform repairs. Therefore, the use of long-term service products is recommended to ensure sustainability for a longer time.

In addition, several technical solutions were shown to increase the PV system's reliability and sustainability. Lastly, the technology recommendations are added in this paper to reduce the O\&M costs and to keep the PV microgrid lifetime as long as possible such as online monitoring solution, PV and battery lifetime estimation, load forecasting, and PV inverters technologies. Further research is still needed to find the optimal planning, design, operation, and maintenance while constraining costs, and how to deploy the technology to reduce the operation and maintenance costs.

Author Contributions: Conceptualization, D.S.; Data curation, R.M., S.B. and A.S.; Formal analysis, D.S., N.M. and A.S.; Funding acquisition, N.M., J.P. and F.L.; Investigation, D.S., N.M. and S.B.; Methodology, D.S.; Project administration, I.S., R.M. and J.P.; Resources, I.S. and F.L.; Supervision, N.M. and J.P.; Writing—original draft, D.S.; Writing—review \& editing, D.S., I.S., N.M., R.M. and J.P. All authors have read and agreed to the published version of the manuscript.

Funding: This publication is part of the project ANRGI-Accessible, Natural, Renewable, Growing, Interactive/Implementations with project number 482.19 .510 of the research programme NWO Merian Fund: Cooperation Indonesia-The Netherlands Renewable Energy 2019 which is (partly) financed by the Dutch Research Council (NWO).

Institutional Review Board Statement: Not applicable.

Informed Consent Statement: Not applicable.

Data Availability Statement: Restrictions apply to the availability of these data. Data was obtained from PLN and are available from authors with the permission of PLN.

Conflicts of Interest: The authors declare no conflict of interest. The funders had no role in the design of the study; in the collection, analyses, or interpretation of data; in the writing of the manuscript, or in the decision to publish the results.

\section{References}

1. Gardiner, M.; Gardiner, P. Indonesia's Demographic Dividend or Window of Opportunity? Available online: https://media.neliti. com/media/publications/151041-EN-indonesias-demographic-dividend-or-windo.pdf (accessed on 10 August 2021).

2. Asian Development Bank. Achieving Universal Electricy Access in Indonesia. Available online: https://www.adb.org/sites/ default/files/publication/182314/achieving-electricity-access-ino.pdf (accessed on 10 August 2021).

3. Ministry of Energy and Mineral Resource Republic of Indonesia Rasio Elektrifikasi Tahun. 2020. Available online: https: / / onemap.esdm.go.id/news/rasio_elektrifikasi.html (accessed on 9 July 2021).

4. Direktoral Jenderal Ketenagalistrikan. Statistik Ketenagalistrikan 2019. Available online: https://gatrik.esdm.go.id/assets/ uploads/download_index/files/c5eff-statistik-ketenagalistrikan-2019-final-pdf (accessed on 30 May 2021).

5. Kementerian Energi dan Sumber Daya Mineral. Statistik Ketenagalistrikan 2018. Available online: http://alpha.djk.esdm.go.id/ pdf/Buku\%20Statistik\%20Ketenagalistrikan/Statistik\%20Ketenagalistrikan\%20T.A.\%202019.pdf (accessed on 30 May 2021).

6. Kementerian Kelautan dan Perikanan. 111 Pulau-Pulau Kecil Terluar (PPKT) di Indonesia. Available online: https://kkp.go.id/ $\mathrm{djprl/p4k/infografis-detail/5794-111-pulau-pulau-kecil-terluar-ppkt-di-indonesia} \mathrm{(accessed} \mathrm{on} 30$ May 2021). 
7. IEEE Std. 2030.9-2019 Recommended Practice for the Planning and Design of the Microgrid; IEEE: Piscataway, NJ, USA, $2019 ;$ pp. 1-46. Available online: https:/ / ieeexplore.ieee.org/document/8746836 (accessed on 30 May 2021).

8. Khodaei, A.; Bahramirad, S.; Shahidehpour, M. Microgrid Planning Under Uncertainty. IEEE Trans. Power Syst. 2015, 30, 2417-2425. [CrossRef]

9. Ngamroo, I.; Vachirasricirikul, S. Design of Optimal SMES Controller Considering SOC and Robustness for Microgrid Stabilization. IEEE Trans. Appl. Supercond. 2016, 26, 1-5. [CrossRef]

10. Reber, T.; Burman, K.; Hirsch, B. Sustainable Energy for Remote Indonesian Grids: Strategies to Accelerate Nationwide Deployment. Available online: https:/ / www.nrel.gov/docs/fy17osti/66548.pdf (accessed on 30 May 2021).

11. Yan, B.; Luh, P.B.; Warner, G.; Zhang, P. Operation and Design Optimization of Microgrids with Renewables. IEEE Trans. Autom. Sci. Eng. 2017, 14, 573-585. [CrossRef]

12. NZMATES Personnel. Personal Interview, Maluku, Indonesia, 30 April 2021.

13. Solanki, B.; Bhattacharya, K.; Cañizares, C. A sustainable energy management system for isolated microgrids. IEEE Trans. Sustain. Energy 2017, 8, 1507-1517. [CrossRef]

14. Bandyopadhyay, S.; Mouli, G.R.C.; Qin, Z.; Elizondo, L.R.; Bauer, P. Techno-Economical Model Based Optimal Sizing of PV-Battery Systems for Microgrids. IEEE Trans. Sustain. Energy 2020, 11, 1657-1668. [CrossRef]

15. Colson, C.; Nehrir, M.; Sharma, R.; Asghari, B. Improving sustainability of hybrid energy systems part I: Incorporating battery round-trip efficiency and operational cost factors. IEEE Trans. Sustain. Energy 2014, 5, 37-45. [CrossRef]

16. Colson, C.; Nehrir, M.; Sharma, R.; Asghari, B. Improving sustainability of hybrid energy systems part II: Managing multiple objectives with a multiagent system. IEEE Trans. Sustain. Energy 2014, 5, 46-54. [CrossRef]

17. Fadhilah, A.P. Report on the Operational Status of Rural Micro-Hydro Power and Photovoltaic Mini-Grids in Indonesia; Energising Development (EnDev); Deutsche Gesellschaft für Internationale Zusammenarbeit (GIZ): Jakarta, Indonesia, 2017.

18. Thale, S.; Wandhare, R.; Agarwal, V. A novel reconfigurable microgrid architecture with renewable energy sources and storage. IEEE Trans. Ind. Appl. 2015, 51, 1805-1816. [CrossRef]

19. Simatupang, D.P.; Choi, J. Integrated Photovoltaic Inverters Based on Unified Power Quality Conditioner with Voltage Compensation for Submarine Distribution System. Energies 2018, 11, 2927. [CrossRef]

20. Simatupang, D.P.; Choi, J. PV Source Inverter with Voltage Compensation for Weak Grid Based on UPQC Configuration. In Proceedings of the IEEE 18th International Power Electronics and Motion Control Conference (PEMC), Budapest, Hungary, 26-30 August 2018.

21. Statista. Share of Rural Population in Indonesia from 2010 to 2019. Available online: https:/ / www.statista.com/statistics/760959 /indonesia-share-of-rural-population/ (accessed on 30 May 2021).

22. Laporan Kinerja Ditjen Ketenagalistrikan. 2019. Available online: https://www.esdm.go.id/assets/media/content/contentlaporan-kinerja-ditjen-ketenagalistrikan-2019.pdf (accessed on 21 June 2021).

23. PLN Personnel. Personal Interview, Houston, TX, USA, 16 June 2021.

24. PLN Personnel. Personal Interview, Houston, TX, USA, 6 July 2021.

25. Bauer, P. Efficiency Comparison of different Microgrid Layouts Part 2. Available online: https:/ / ocw.tudelft.nl/course-lectures/ 2-4-3-efficiency-comparison-different-microgrid-layouts-part-2/ (accessed on 21 June 2021).

26. Datasheet of GFX (OPzS) Series Acid-Proof Stationaty Battery. Available online: http:/ / www.invertor.ru/teh_akb/OPzS/GFXseries.pdf (accessed on 15 October 2021).

27. Harmon, E.; Ozgur, U.; Cintuglu, M.H.; de Azevedo, R.; Akkaya, K.; Mohammed, O.A. The Internet of Microgrids: A Cloud-Based Framework for Wide Area Networked Microgrids. IEEE Trans. Ind. Inform. 2018, 14, 1262-1274. [CrossRef]

28. Kulkarni, S.; Gu, Q.; Myers, E.; Polepeddi, L.; Liptak, S.; Beyah, R.; Divan, D. Enabling a Decentralized Smart Grid Using Autonomous Edge Control Devices. IEEE Internet Things J. 2019, 6, 7406-7419. [CrossRef]

29. Wang, Z.L.; Chen, J.; Long, L. Progress in Triboelectric Nanogenerators as a New Energy Technology and Self-Powered Sensors. Energy Environ. Sci. 2015, 8, 2250-2282. [CrossRef]

30. Zhao, X.; Askari, H.; Chen, J. Nanogenerators for smart cities in the era of 5G and Internet of Things. Joule 2021, 5, $1391-1431$. [CrossRef]

31. Syafaruddin, S.; Karatepe, E. Controlling of artificial neural network for fault diagnosis of photovoltaic array. In Proceedings of the 16th International Conference on Intelligent System Applications to Power Systems (ISAP), Hersonissos, Greece, 25-28 September 2011.

32. Niccolai, A.; Grimaccia, F.; Leva, S. Advanced Asset Management Tools in Photovoltaic Plant Monitoring: UAV-Based Digital Mapping. Energies 2019, 12, 4736. [CrossRef]

33. Kwiecien, M.; Badeda, J.; Huck, M.; Komut, K.; Duman, D.; Sauer, D.U. Determination of SoH of Lead-Acid Batteries by Electrochemical Impedance Spectroscopy. Appl. Sci. 2018, 8, 873. [CrossRef]

34. Majchrzycki, W.; Jankowska, E.; Baraniak, M.; Handzlik, P.; Samborski, R. Electrochemical Impedance Spectroscopy and Determination of the Internal Resistance as a Way to Estimate Lead-Acid Batteries Condition. Batteries 2018, 4, 70. [CrossRef]

35. Guha, A.; Patra, A. Online Estimation of the Electrochemical Impedance Spectrum and Remaining Useful Life of Lithium-Ion Batteries. IEEE Trans. Instrum. Meas. 2018, 67, 1836-1849. [CrossRef]

36. Dharma, A.; Robandi, I.; Purnomo, M.H. Application of Interval Type-2 Fuzzy Logic System in Short Term Load Forecasting on Special Days. IPTEK J. Technol. Sci. 2011, 22, 110-116. [CrossRef] 
37. Aprillia, H.; Yang, H.-T.; Huang, C.-M. Optimal Decomposition and Reconstruction of Discrete Wavelet Transformation for Short-Term Load Forecasting. Energies 2019, 12, 4654. [CrossRef]

38. Hernández, L.; Baladrón, C.; Aguiar, J.M.; Carro, B.; Sánchez-Esguevillas, A.; Lloret, J. Artificial neural networks for short-term load forecasting in microgrids environment. Energy 2014, 75, 252-264. [CrossRef]

39. Dai, S.; Niu, D.; Li, Y. Daily peak load forecasting based on complete ensemble empirical mode decomposition with adaptive noise and support vector machine optimized by modified grey wolf optimization algorithm. Energies 2018, 11, 163. [CrossRef]

40. Ghelardoni, L.; Ghio, A.; Anguita, D. Energy Load Forecasting Using Empirical Mode Decomposition and Support Vector Regression. IEEE Trans. Smart Grid 2013, 4, 549-556. [CrossRef]

41. Dong, M.; Grumbach, L. A Hybrid Distribution Feeder Long-Term Load Forecasting Method Based on Sequence Prediction. IEEE Trans. Smart Grid 2020, 11, 470-482. [CrossRef]

42. Yuan, J.; Blaabjerg, F.; Yang, Y.; Sangwongwanich, A.; Shen, Y. An Overview of Photovoltaic Microinverters: Topology, Efficiency, and Reliability. In Proceedings of the 2019 IEEE 13th International Conference on Compatibility, Power Electronics and Power Engineering (CPE-POWERENG), Sonderborg, Denmark, 23-25 April 2019.

43. MacApline, S.; Deline, C. Modeling Microinverter and DC Power Optimizer in PVWatts. Available online: https://www.nrel. gov/docs/fy15osti/63463.pdf (accessed on 21 June 2021). 